\title{
Proactive Civil Society to Achieve SDGs
}

\author{
Celia Pinedo Pardo ${ }^{1}$.
}

\begin{abstract}
This Article has the aim to show how crucial civil society proactive role is to achieve 2030 Agenda. It focusses especially in South regions' rural areas where communities have never had the opportunity to design and lead their own development.

SDGs motto states "leaving no one behind". However, we still find that one of the great problems regarding 2030 Agenda achievement is the generalized ignorance of what "S-D-G" mean.

To tackling these issues, it is essential to provide the necessary tools to population (especially in rural areas) to let them know how they can really be actors of an inclusive sustainable global development and to make them aware that development is a human right recognized to all individuals.

This Article it's about the international partnership for the 17 goals that reunites more than 150 proactive children and young people from San Marcos (Guatemala), Poroma (Bolivia), Yamoussoukro (Ivory Coast) and Navarre (Spain). A Non-governmental organization initiative supported by public authorities and based on a $\mathrm{PhD}$ research that defends why small local projects promoted by children and youth people are essential to achieve SDGs.

There are currently 25 local projects running as a result of this Education for Development program that boosts North-South and South-South cooperation.
\end{abstract}

Keywords: Education for Development, proactivity, Agenda 2030, society empowerment, South-South cooperation, right to development.

\section{Introduction}

It is a universal necessity and a recognized human right that all women and men, girls and boys, regardless of nationality, race, sex, religion or any other social or personal condition, enjoy a dignified life. The idea of achieving global sustainable development, under conditions of equality, occupies a great deal of international practice. After all, in each and every place on the planet there is a concern for peace and security, and for that, experience has shown that it is essential to eradicate poverty in all its ways.

Poverty eradication is a global problem that affects multiple spheres of social reality. Not only is it the starting point to achieve the desired global development, peace and security; but also, poverty elimination is a fundamental pillar to win the battle of inequality between women and men, strengthen strong and just forms of government that respect and recognize human rights, promote universal quality education, conserve the environment or combat contagious diseases that cause thousands of daily deaths. 
Precisely, with the priority aim of continue battling global poverty, were conceived the Sustainable Development Goals (SDGs) by the United Nations in the ambitious 2030 Agenda, September 25, 2015. Seventeen goals to achieve sustainable development, a universal commitment to reach them and a date to do it: the year 2030.

2030 Agenda states that "each country has primary responsibility for its own economic and social development". It appeals as well to international cooperation responsibility. It recognizes the importance of Official Development Assistance (ODA) and the necessity of achieving the 0 ' 7 commitment by many developed countries. Moreover, 2030 Agenda refers concretely to the essential role that civil society plays in the implementation of SDG 17 and 169 targets.

Actually, it should be a reality and not a purpose that every human person and all peoples "participate in, contribute to, and enjoy economic, social, cultural and political development, in which all human rights and fundamental freedoms can be fully realized". However, reality shows that many communities all around the world have never had the opportunity to design and lead their own development. In other words, a large portion of the world's population has never exercised the right to development and, consequently, has never enjoyed SDGs impact.

This Article starts form the idea that development is a human right recognized to all individuals. In this sense, SDGs are a new expression of international efforts to make this human right real. To support this statement is necessary to address the debate on development as a human right.

This premise is essential to understand the importance of projects that empower people by making them designer and leader of their own development. This Article presents the results of an Education for Development project carried out in Guatemala, Bolivia, Ivory Coast and Spain. An international partnership for the global goals that reunites more than 150 proactive children and youth leading small local projects. An initiative that is transforming 4 small communities and, at the same time, is contributing to achieve global sustainable development.

\section{SDGs: a new expression of the right to development.}

It has been discussed in the internationalist doctrine whether the right to development, as a subjective right, is or not a fundamental right. As stated by Gomez Isa (1998), it is criticized that an excessive proliferation of human rights can "weaken the protection of existing human rights". However, the purpose of the right to development is far from weakening existing human rights, because this right allows precisely to enjoy such human rights. In fact, according to Vasak (1990), the right to development is a "synthesis right", i.e. a right that integrates the entire set of human rights and whose ultimate target is to promote and apply these. 
In the words of Gros Espiell (1996) "without a development that guarantees the necessary material, political and cultural conditions, human rights cannot become a real and vital truth".

The debate on development arises for the first time with the process of decolonization in 1960. As Truyol y Serra (1974) said, "the tremendous inequalities between developed and developing countries created a general awareness with regard to the need to cooperate in order to promote socioeconomic progress and made emerge and progress the idea of joint responsibility in the fight against poverty and underdevelopment".

It is from 1960 on, when internationalists started to talk about development. That same year, in the historical Resolution 1515 (XV) of the General Assembly of the United Nations, the important role of the United Nations towards development problems was affirmed for the first time. Development as a human right was legally formalized in the 1986 "Right to Development Declaration" in Ruling $41 / 128$ of the UN General Assembly.

Since then, International Cooperation has been the principal tool to make this human right real. There is no universal definition of international cooperation for development. According to Argibay (2007), "cooperation for development brings together the set of policies, activities, projects and programs elaborated to collaborate with people, peoples, regions or countries that need support to improve their living conditions, to fully develop their potential to reach a dignified and autonomous life. Although not without contradictions, cooperation for development is the most generous and most humane line of action in international relations."

On her part, Barbé (2000) emphasizes that "international cooperation for development is a specialized area of international practice that encompasses all the activities, resources and possibilities that developed countries carry out, make available or facilitate to underdeveloped or developing countries with the objective of favoring its economic and social development". Sotillo (2011) adds that all this framework must be executed "with some specific purposes (democratic consolidation, sustainable economic and social development, fight against poverty, protection of the environment, among others), and raised in terms of co-responsibility between counterparts."

The international organization that has most promoted international cooperation for development is the United Nations (UN). Through its various specialized agencies, offices and organisms, the UN leads cooperation.

Within the actions for development carried out by the UN, it is worth stressing the so-called Millennium Declaration, September 8, 2000. In the Resolution 55/2 of the General Assembly, the UN proposed a set of precise goals accompanied by specific targets and compliance indicators, known as the Millennium Development Goals (MDGs), to be met in 2015. That September 8, in New 
York, 189 heads of State or Government committed to carry out the necessary policies so that in 2015 people could live with dignity. Poverty, education, gender equality, health, environment... these are key to achieve development. But 2015 came and went.

Nevertheless, progress has been done. According to the latest MDGs report (2015), the number of people living below the extreme poverty line - 1900 million in 1990 - was reduced by half upon closing the MDGs in 2015.

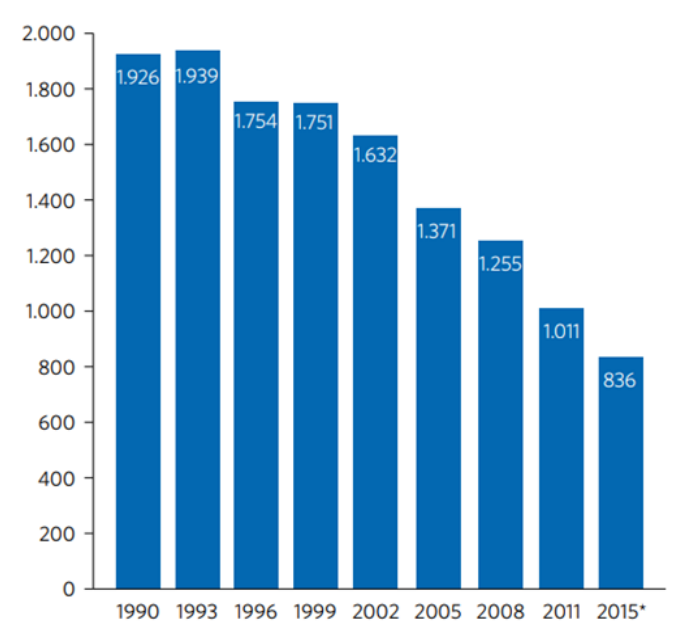

Chart I: Number of people in the world living on less than 1.25 US dollars a day, 1990-2015* (in millions). Source: Millennium Development Goals Report 2015.

However, it is clear that the eight MDGs have not been reached. Moreover, with the threats of terrorism and radicalization, climate change, unequal progress, the rise of a "new poverty" due to the global economic crisis and "new forms of slavery", the "post-2015" challenges are even greater.

For this reason, when in 2012 those who promoted MDGs realized it was virtually impossible to meet the goals by the scheduled date, they began to reflect on what future would be desirable after 2015 and studied how to achieve it. The then Secretary General of the UN, Ban Ki-moon, established a Working Group to design what would be the Post-2015 Development Agenda. Meetings, summits, the famous Rio +20 Conference came in three years of many documents and negotiations, where there was always something clear: the new agenda would have to be based on sustainability. The objective would be to achieve sustainable development.

In December 2015, the so-called Sustainable Development Goals (SDGs) were published and accepted by 193 countries. The Resolution 70/1 of the General Assembly of the UN established 17 goals, which implied the achievement of 169 very specific targets, to be met by 2030 and measured with 230 indicators. 2030 Agenda is a new roadmap, an innovative, transversal and inclusive text, representing a great opportunity to incorporate the lessons learned with MDGs and respond more effectively and realistically to international challenges. 
2030 Agenda states that, in order to ensure its implementation, a revitalized Global Partnership is necessary, as an intensive global engagement that brings together Governments, the private sector, civil society, the UN system and other actors.

Among members of civil society, 2030 Agenda gives a key role to youth and children. It proclaims that "children and young women and men are critical agents of change and will find in the new Goals a platform to channel their infinite capacities for activism into the creation of a better world."

The idea of youth and children being true 2030 Agents is now becoming a reality through an international partnership. It arises as part of the Education for Development project executed by the FABRE Foundation.

Education for Sustainable Development (ESD) is a branch of international cooperation that empowers people to change the way they think and work towards a sustainable future. There is growing international recognition of ESD as an integral element of quality education and a key enabler for sustainable development.

Target 4.7 of SDG 4 on quality education stablishes that, by 2030, we must "ensure that all learners acquire the knowledge and skills needed to promote sustainable development, including, among others, through education for sustainable development and sustainable lifestyles, human rights, gender equality, promotion of a culture of peace and non-violence, global citizenship and appreciation of cultural diversity and of culture's contribution to sustainable development".

FABRE Foundation in Navarre (Spain) implements an ESD project that shows that small local projects promoted by children and young people are essential to achieve SDGs. This project has the technical support of Guatemalan, Bolivian and Ivorian FABRE's counterparts, the public funding of the Government of Navarre and the scientific support of the University of Navarre.

\section{2030 Agents making \#iDeas2030 happen: Proactive youth and children to achieve SDGs.}

FABRE international initiative promotes youth and children to experience the inclusive and universal nature of global goals. A total of 21 schools in San Marcos (Guatemala), Poroma (Bolivia), Navarra (Spain) and Yamoussoukro (Ivory Coast) are involved, fostering mutual knowledge and cooperation in ESD (North-South and South-South). Youth and children from the 4 countries create and execute joint innovative ideas to reach the goals in the North and in the South: this is done via social networks, reaching through FABRE's local partners where it does not arrive Internet, thus facing digital gap. 
More than 150 proactive children and young people are true 2030 Agents making their \#iDeas2030 happen. They come from rural areas with extreme poverty in Guatemala and Bolivia, disadvantaged urban areas in the capital of the Ivory Coast and communities in risk of social exclusion in Spain. In essence, these are young people and children that wouldn't otherwise have the opportunity to design and lead their own development.

In addition to the achieving of SDGs, this initiative intends to implement an experiential learning process, with the intention of setting values and attitudinal competencies that agree with the philosophy of the 2030 Agenda. The combination of the cognitive, emotional and face-to-face methodologies are sought through dialogue and the exchange of experiences and knowledge.

Local projects carried out by youth and children revolve around a maker-based learning methodology. This methodology was born in the United States with the teaching of science and technology. It enhances higher order thinking skills (assess, analyze and create) and is also essential in the promotion of proactivity and social entrepreneurship. This methodology allows youth and children to participate in the project by selecting their own learning and action path based on a model of personal inquiry.

The project process starts with a training in SDGs. Then, Guatemalan, Bolivian, Ivorian and Spanish children and young people from 3 to 25 years old lead local projects with this structure:

$1^{\text {st }}$ step: INSTAGRAM - Identify the problem, take a picture of it and post it on Instagram!

Each group analyzes the social-economic-cultural reality of their community and identifies several existing problems. They select a concrete problem and associate it with one SDG. They take a picture of that problem and post it in Instagram with the hashtag \#iDeas2030.

During this first phase of the initiative, Guatemalan, Bolivian, Ivorian and Spanish young people and children discover from what angle problems are viewed and analyzed in other places of the world. They are aware that 2030 Agenda really addresses global development issues that, although in a different way, affect all points of the planet.

$2^{\text {nd }}$ step: TWITTER - Design an idea to solve the problem and post it on Twitter!

Each group brainstorms about how to solve the photographed problem. The goal is that young people and children become major player of the change aware that, no matter the age or place in the world someone live, we are all responsible of sustainable development. During this second step, creativity, proactivity and leadership are promoted. 
Each group selects an ambitious but realistic idea and post it on Twitter. These ideas are shared all around the world, being inspiration for other people.

$3^{\text {rd }}$ step: YOUTUBE - Make the \#iDea2030 happen, shoot it and post it on YouTube!

During a period of 4 months, each group creates an action plan, executes the \#iDea2030 and records it showing the impact in the community. Each video is shared on FABRE's YouTube channel.

All these videos give voice to all those children and young people who, at a local level and in disadvantages areas, are transforming the world in a more sustainable, equitable and fair one.

There are currently 25 local projects running as a result of this ESD project that boosts North-South and South-South cooperation. As an example of this process, one particular case can be mentioned:

SDG 11: Sustainable cities and communities. Project in Cantón Mariscal village, San Marcos department, Guatemala - Group formed by Angee Lopez, Shannel Bautista and Linda Ramirez, 10 years old.

Photographed problem: slums in their village - substandard housing (target 11.1). \#iDea2030: mobilizing the major of their town to ensure decent housing for the population.

Impact: Three Guatemalan girls broke stereotypes and machismo barriers latent in their community. Women in their village aren't allowed to participate in the political sphere and to raise their voice against injustices. With this initiative, they asked for an audience with the major of their town and demanded him to facilitate building material and electricity to families living in slums. The engagement was twin-track: the municipality facilitates materials and families build their houses.

\section{Conclusions: a methodology of empowerment to be replicated.}

SDGs motto states "leaving no one behind". Several targets among SDGs 17 note the need to focus efforts in indigenous peoples, persons with disabilities, women, youth and children in vulnerable situations.

2030 Agenda text encourages "Member States to conduct regular and inclusive reviews of progress at the national and subnational levels which are country-led and country-driven. Such reviews should draw on contributions from indigenous peoples and civil society".

It claims that the road to 2030 involves "Governments as well as parliaments, the UN system and other international institutions, local authorities, indigenous peoples, civil society, business and the private sector, the scientific and academic 
community - and all people. Millions have already engaged with, and will own, this Agenda."

However, we find that reality is far away from this 2030 purpose of inclusion. People in disadvantaged communities don't even know what "S-D-G" mean. What is more, children and youth FABRE works with in Guatemala, Bolivia, Spain and the Ivory Coast don't realize that they can be lead actors to achieve it. It is absolutely imperative to design and carry out new initiatives that allow all groups of civil society - and not only just a few advantaged ones - to be owner of their social-economic-cultural sustainable development.

This NGO initiative supported by public authorities and based on a $\mathrm{PhD}$ research shows why small local projects promoted by children and youth people are essential to achieve SDGs.

Now the challenge is to replicate this \#iDeas2030 methodology with adult people and in other disadvantaged communities in the world. In essence, our final goal is to ensure inclusive democratic governance and to promote fair and participatory societies. There where the fundamental freedoms of all people are protected and the effective involvement of citizens in decision-making regarding the achievement of the 2030 Agenda is guaranteed. Because, "it is an Agenda of the people, by the people and for the people - and this, we believe, will ensure its success."

\section{References}

Argibay, Miguel, Cooperación para el desarrollo, in Celorio Gema y López de Muniain Alicia, Diccionario de Educación para el Desarrollo. Hegoa: Bilbao, 2007, p. 63.

Barbé, Esther. La cooperación para el desarrollo de la Comunidad Europea: naturaleza, mecanismos y políticas. Ariel: Barcelona, 2000, p.60.

Doc. A/RES/70/1, September 25, 2015, p.10-12.

Doc. A/RES/41/128, December 4, 1986, Article 1.

Gómez Isa, Felipe. El derecho al desarrollo: entre la justicia y la solidaridad. Bilbao: University of Deusto, 1998, p.10.

Gross Espiell, Héctor. El Derecho al Desarrollo veinte años después. Balance y perspectiva, in Herrero de la Fuente, Alberto (Coord.), Reflexiones tras un año de crisis. Valladolid: University of Valladolid, 1996, p.51

Sotillo, José Ángel. El sistema de cooperación para el desarrollo. Catarata: Madrid, 2011, p.69

Truyol y Serra, Antonio. L'expansion de la société internationale aux XIX et XX siècles, Recueil des Cours de l'Académie de Droit International, Madrid: Alianza Editorial, 1974, p.84

Universal Declaration of Human Rights. General Assembly of the United Nations, December 10, 1948, Paris, (Article 25)

Vasak, Karel. Les différentes catégories des Droits de l'homme, en Les dimensions universelles des Droits de l'homme, UNESCO-Bruylant, Bruxelles, 1990, p.297 